DOI: 10.17707/AgricultForest.62.2.03

\author{
Gordan S. KARAMAN ${ }^{1}$
}

\title{
ONE NEW MEMBER OF THE SUBTERRANEAN FAMILY NIPHARGIDAE FROM SPAIN, NIPHARGUS SPIRITUS, SP. N. (CONTRIBUTION TO THE KNOWLEDGE OF THE AMPHIPODA 291)
}

\begin{abstract}
From the subterranean waters of the northern Spain, Fuente Aizpara, on the northern slope of Aizpara Mt., Zugarramurdi, Navarra, one new species of the family Niphargidae (Crustacea, Amphipoda, Gammaridea) is described and figured, Niphargus. spiritus, sp. n. This species is characterized by presence of scarce number of additional spines on some of pereopod-dactyls, elongated inner ramus of uropod 1 and distal article of uropod 3 in males, long spines on telson, numerous setae along outer margin of dactylus on gnathopods 1 and 2, by presence of only 1-2 setae on maxilla 1 inner plate, etc. The relation between $N$. spiritus and other known species of this genus known from Spain and France is discussed.
\end{abstract}

Keywords: taxonomy, Amphipoda, new species, Niphargus spiritus, Spain.

\section{INTRODUCTION}

The genus Niphargus Schiödte, 1849 (Amphipoda, family Niphargidae) is widely spread over Europe and Near East, on west to Great Britain and France, but in Spain is present in the northern part of Iberian Peninsula only, mainly towards French border.

The number of known taxa of genus Niphargus in Spain is very scarce. Margalef (1952) described a new taxon Niphargus ciliatus cismontanus, ssp.n. from Guipuzcoa (Aranzazu: cueva de Guesaltza). G. Karaman mentioned (1986a) Niphargus delamarei Ruffo 1954 from Mosquera cave (= Cova de la Mosquera), Beuda, Gerona province, and later (2015a) described Niphargus notenboomius, sp. n, and N. laisi geronensis, ssp. n.. He cited (2015b) Niphargus gallicus Schell., 1935 and N. delamarei Ruffo, 1954 for several new Spanish localities. Our recent study of material from Spain, collected by Prof. Dr. Jos Notenboom and other collectors, indicated the presence of some other taxa of this genus in Spain, related to the known species from France. Here is presented the results of study of part of these samples.

\footnotetext{
${ }^{1}$ Gordan S. Karaman (corresponding author: karaman@t-com.me) Montenegrin Academy of Sciences and Arts, Podgorica, Montenegro Note: The authors declare that they have no conflicts of interest. Authorship Form signed online.
} 


\section{MATERIAL AND METHODS}

The studied material was preserved in $70 \%$ ethanol. Collected specimens were dissected using a WILD M20 microscope and drawn using a camera lucida. All appendages were temporarily submersed in a mixture of glycerine and freshwater for study and drawing. The body-length of examined specimens was measured from the tip of head to the end of the telson using a camera lucida. All illustrations were manually drawn in ink. After the end of the study, dissected body-parts were submerged in Liquid of Faure and covered by thin cover glass to dry.

Some morphological terminology and seta formulae follow Karaman`s terminology (Karaman G., 1969, 2012b): for the last mandibular palpus [A= setae on outer face; $B=$ setae on inner face; $C=$ additional setae on outer face; $D=$ lateral marginal setae; $\mathrm{E}=$ distal long setae] and for propodus of gnathopods 1 and 2 [S= corner spine; $\mathrm{L}=$ lateral slender serrate spines; $\mathrm{M}=$ facial $\mathrm{M}$-setae; $\mathrm{R}=$ subcorner spine on inner face]. Terms "setae" and "spines" are used based on shape, not origin. The studies are provided based on morphological, ecological and zoogeographical data.

\section{TAXONOMICAL PART}

\section{Family NIPHARGIDAE}

\section{NIPHARGUS SPIRITUS, sp. n.}

Figs 1-8.

MATERIAL EXAMINED:

SPAIN: - 84-6/28, Fuente Aizpara, on the northern slope of Aizpara Mt., Zugarramurdi, Navarra, coord.: XN 193917, 320 m, 16.6.1984,, 8 exp. (leg. Notenboom, J. \& Meijers, I.).

\section{DIAGNOSIS}

Antenna 1 peduncular articles 1-3 progresively shorter; flagellum of antenna 2 longer than last peduncular article; outer plate of maxilla 1 with 7 spines (most of them with one lateral tooth each). Coxae short, coxa 4 without posterior lobe; propodus of gnathopods 1-2 trapezoid, with one S-spine accompanied laterally by $3 \mathrm{~L}$-spines; dactylus of gnathopods $1-2$ with row of setae along outer margin; dactylus of pereopods 3-5 with 1-2 strong spines at inner margin. Article 2 of pereopods 5-7 poorly to distinctly lobed; pleopods with 2 retinacula and scarcely setose peduncle; epimeral plate 3 nearly angular.

Uropod 1 in male with inner ramus remarkably longer than outer one and bearing short spines and bunches of setae; uropod 2 inner ramus slightly longer than outer one; uropod 3 with scale-like inner ramus, outer ramus with 2 long articles. In female, inner ramus of uropod 1 is slightly longer than outer one, and uropod 3 distal article of outer ramus much shorter than first article. Telson is with long distal and marginal spines. 


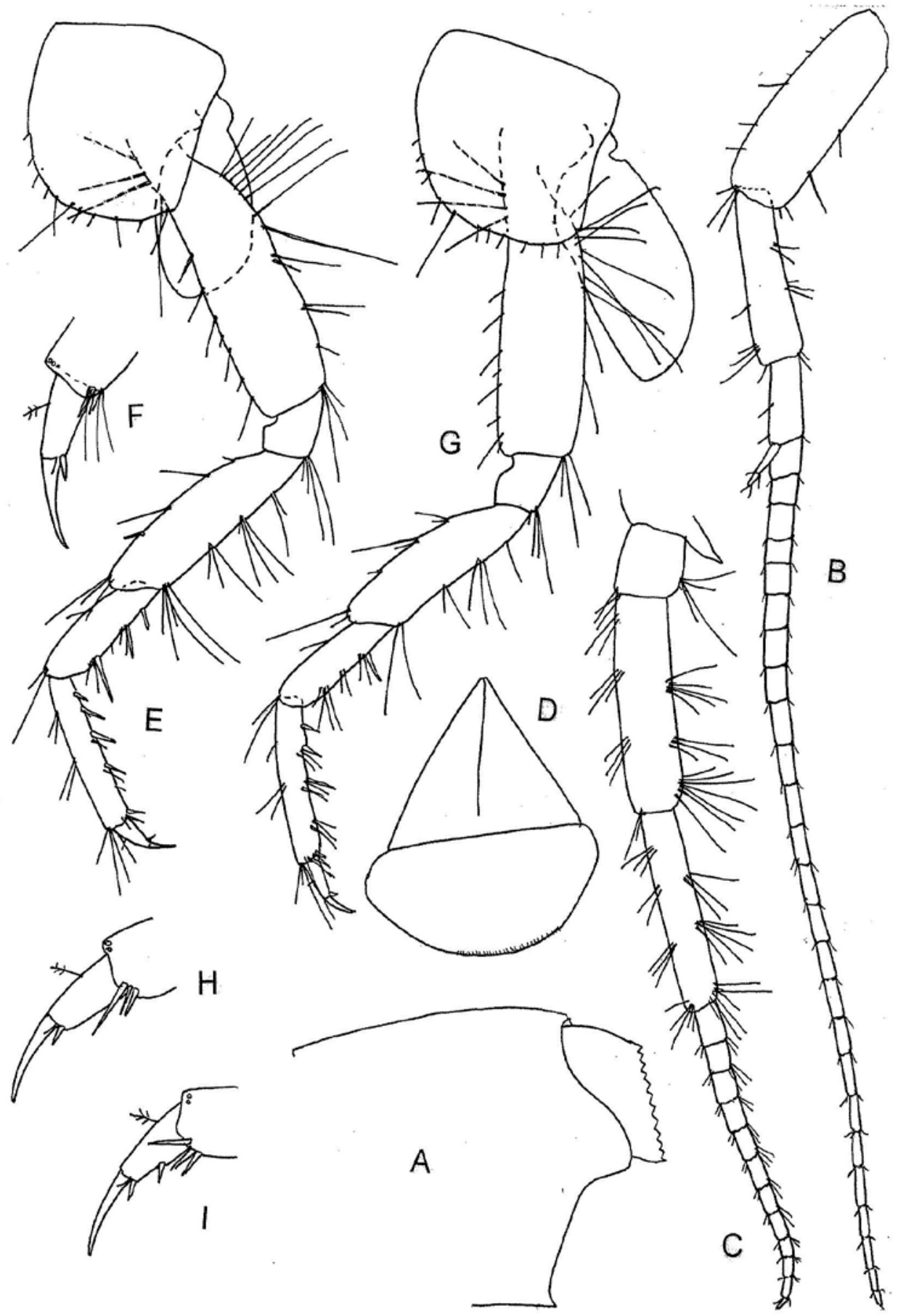

Fig 1. Niphargus spiritus, sp. n., Fuente Aizpara, male $12.0 \mathrm{~mm}$ (holotype). $\mathrm{A}=$ head; $\mathrm{B}=$ antenna $1 ; \mathrm{C}=$ antenna $2 ; \mathrm{D}=$ labrum; $\mathrm{E}-\mathrm{F}=$ pereopod $3 ; \mathrm{G}-\mathrm{H}-\mathrm{I}=$ pereopod 4. 
DESCRIPTION: Male $12.0 \mathrm{~mm}$ (holotype): Body moderately slender, metasomal segments 1-3 at dorsoposterior margin with 8-9 setae each (fig. 5D); urosomal segment 1 on each dorsolateral side with 1 seta; urosomal segment 2 on each dorsolateral side with 2 setae, urosomal segment 3 naked (fig. 3E). Urosomal segment 1 on each ventroposterior corner with one short spine (fig. 3E). Epimeral plates 1-2 poorly angular, with marked ventroposterior corner spine-like seta and convex posterior margin bearing a row of short setae; epimeral plate 3 angular, with marked ventroposterior corner by one spine-like seta and almost straight posterior margin bearing a row of short setae (fig. 5D). Epimeral plate 2 with 1 subventral spine, epimeral plate 3 with 2 subventral spines (fig. 5D).

Head with short rostrum and short subrounded lateral cephalic lobes, ventroanterior sinus is developed, eyes absent (fig. 1A).

Antenna 1 slightly exceeding half of body (7:12), peduncular articles 1-3 progressively shorter (ratio: 60:48:23), scarcely setose; peduncular article 3 is not elongated (fig. 1B); main flagellum consisting of 25 articles (most of them with one short aesthetasc); accessory flagellum 2-articulated, shorter than last peduncular article (fig. 1B).

Antenna 2 remarkably setose (fig. 1C); peduncular article 4 poorly longer than article 5 (ratio: 58:55), along ventral margin with 3 bunches of setae (the longest setae poorly exceeding the diameter of article itself), along dorsal margin with 4 bunches of setae (fig. 1C); article 5 along ventral margin with 3 bunches of setae longer than diameter of article itself, along dorsal margin with 4 bunches of short setae; flagellum slender, remarkably longer than last peduncular article (ratio: 85:55), consisting of 12 articles bearing short setae (fig. 1C). Antennal gland cone short (fig. 1C).

Mouthparts well developed. Labrum is much broader than long, with convex distal margin (fig. 1D).

Labium broader than long, inner lobes well developed, outer lobes subrounded distally (fig. 3A).

Mandible is with triturative molar. Right mandible: incisor with 4 teeth, lacinia mobilis bifurcate, serrate, accompanied by 8 rakers (fig. 5C). Left mandible: molar without long seta, incisor with 5 teeth, lacinia mobilis with 4 teeth, accompanied by 7-8 rakers. Mandibular palpus: article 1 naked; palpus article 2 bearing 15 setae (fig. 5A); palpus article 3 falciform, longer than article 2 (ratio: 83:62), at margin with nearly 23-25 D-setae and 6 distal long E-setae (fig. 5A), on outer face with one bunch of 7 facial A-setae, on inner face by 4 groups of B-setae (fig. 5B).

Maxilla 1: inner plate narrow, with 1 distal seta (fig. 3B), outer plate with 7 spines (1-2 spines with 2 lateral teeth, one spine with 3-4 small lateral teeth, 34 spines with one lateral tooth (fig. 3B), palpus 2-articulated, with 7 distal setae (fig. 3B).

Maxilla 2: both plates slightly unequal long, bearing distolateral setae only (fig. 3C). 


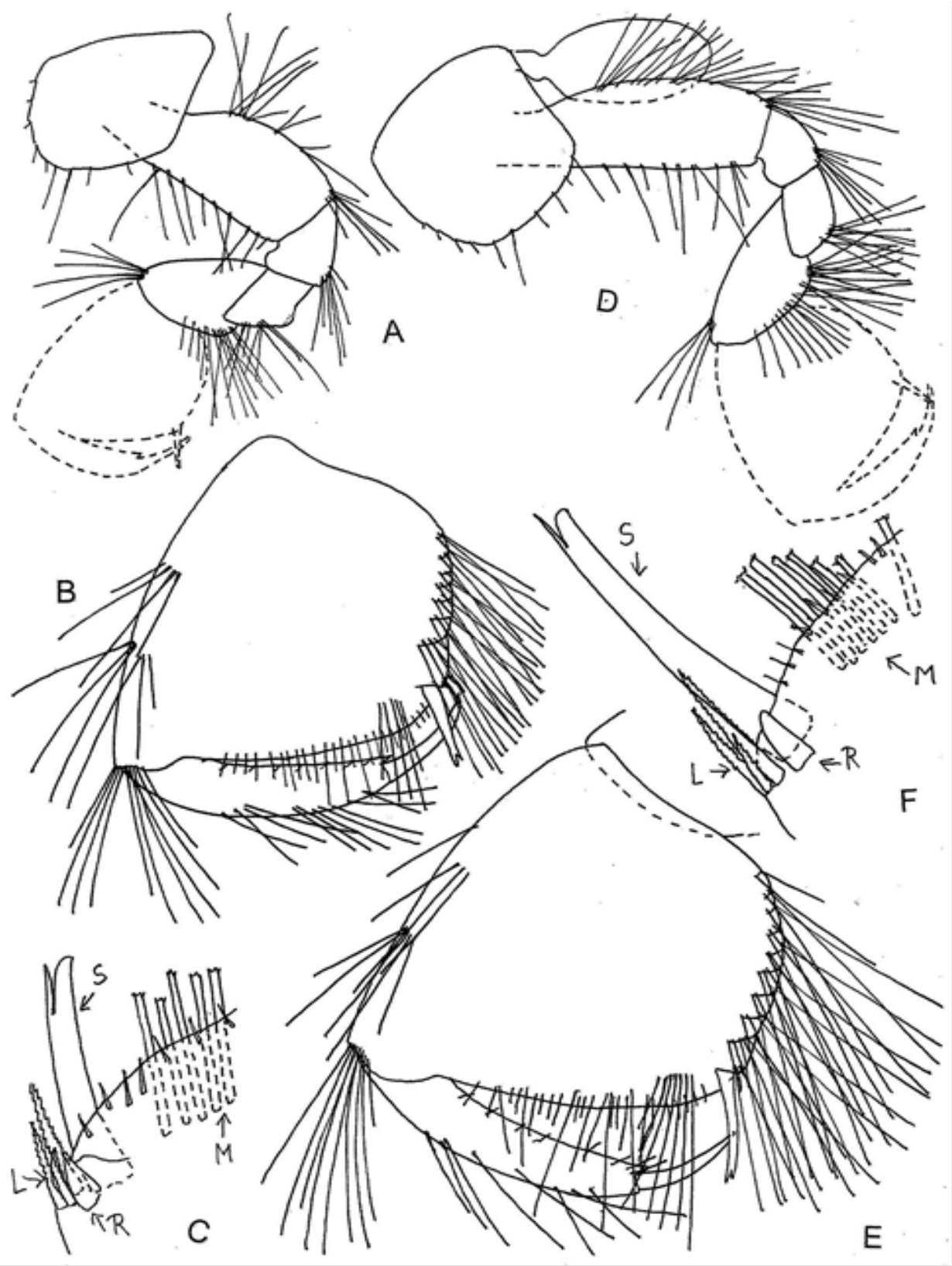

Fig 2. Niphargus spiritus, sp. n., Fuente Aizpara, male 12.0 mm (holotype). A$\mathrm{B}=$ gnathopod 1 , outer face; $\mathrm{C}=$ distal corner of gnathopod 1 propodus, inner face [S=corner spine; $\mathrm{L}=$ lateral spines; $\mathrm{M}=$ facial $\mathrm{M}$-setae; $\mathrm{R}=$ subcorner spine]; $\mathrm{D}$ $\mathrm{E}=$ gnathopod 2, outer face; $\mathrm{F}=$ distal corner of gnathopod 2 propodus, inner face [S= corner spine; $\mathrm{L}=$ lateral spines; $\mathrm{M}=$ facial $\mathrm{M}$-setae; $\mathrm{R}=$ subcorner spine]. 
Maxilliped: inner plate short, not exceeding outer tip of palpus article 1, bearing 3-4 distal smooth spines and several setae (fig. 3D); outer plate nearly reaching half of palpus article 2, bearing a row of distolateral smooth spines (fig. 3D); palpus article 3 at outer margin with one median and one distal bunch of setae; article 4 (dactylus) at inner margin with 2 setae near basis of the nail (fig. $3 \mathrm{D})$, along outer margin with one median seta.

Coxae are relatively short. Coxa 1 broader than long (ratio: 47:35), with subrounded ventroanterior corner, bearing several short and one long seta (fig. 2A). Coxa 2 as long as broad, at ventral margin with row of nearly 10 setae of unequal length (fig. 2D). Coxa 3 nearly as long as broad, with subrounded ventral margin bearing row of nearly 10 unequal marginal setae (fig. 1E). Coxa 4 hardly broader than long (ratio: 54:50), along convex margin with row of nearly 12 unequal marginal setae, ventroposterior lobe absent, posterior margin concave (fig. 1G).

Coxa 5 broader than long (ratio: 66:38), anterior lobe almost as long as coxa 4 (fig. 4A). Coxa 6 smaller than coxa 5, broader than long (ratio: 60:33) (fig. 4C). Coxa 7 entire, broader than long (ratio: 55:22) (fig. 4G).

Gnathopods 1 and 2 relatively small, almost as large as corresponding coxa (fig. 2A, D). Gnathopod 1: article 2 along anterior margin with row of long setae, along posterior margin with bunches of long setae (fig. 2A); article 3 at distoposterior corner with one bunch of longer setae (fig. 2A); article 4 with distoposterior bunches of setae; article 5 shorter than propodus (ratio: 34:50), along anterior margin with distal bunch of setae (fig. 2A).

Propodus trapezoid, longer than broad (ratio: 100:80), along posterior margin with 7 transverse rows of setae (fig. 2B); palm slightly convex, inclined nearly half of propodus-length, defined on outer face by one corner S-spine accompanied laterally by 3 slender serrate L-spines and 5 facial M-setae (fig. 2C), on inner face by 1 subcorner R-spine (fig. 2C); dactylus reaching posterior margin of propodus, along outer margin with row of single or paired setae, at inner margin with row of short setae (fig. 2B).

Gnathopod 2 only slightly larger than gnathopod 1 . Article 2 along anterior margin with row of long and short setae, along posterior margin with bunches of long setae (fig. 2D); article 3 at posterior margin with distal bunch of setae; article 5 shorter than article 6 (ratio: 45:53), at anterior margin with distal bunch of setae (fig. 2D). Propodus trapezoid, slightly longer than broad (ratio: 107:97), along posterior margin with 9 transverse rows of setae (fig. 2E). Palm slightly convex, inclined nearly half of propodus-length, defined on outer face by one corner S-spine accompanied laterally by 3 slender unequal L-spines and 7 facial M-setae (fig. 2F), on inner face by one subcorner R-spine (fig. 2F). Dactylus reaching posterior margin of propodus, along outer margin with row of single and paired setae, along inner margin with row of short setae (fig. 2E) 


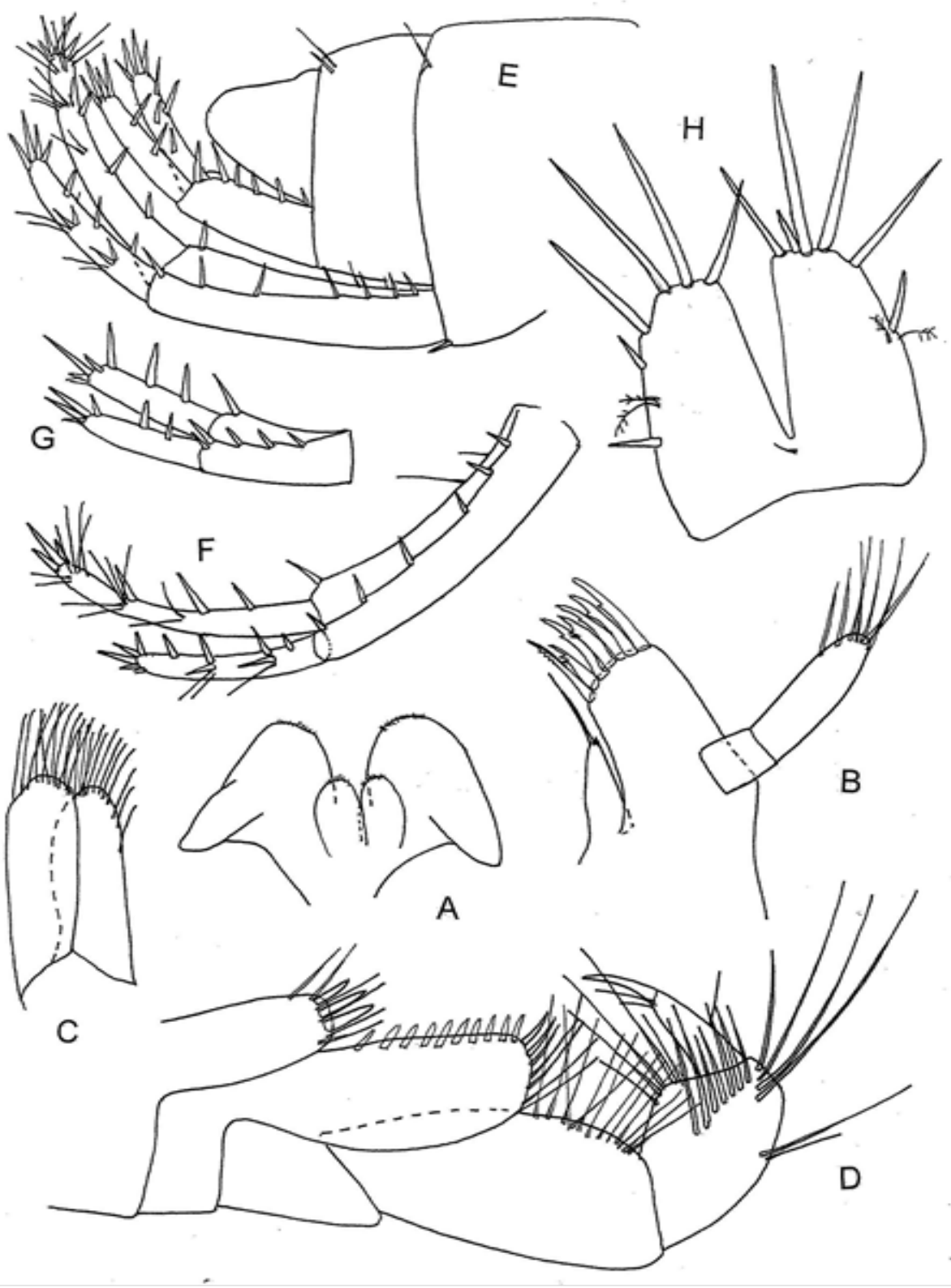

Fig 3. Niphargus spiritus, sp. n., Fuente Aizpara, male $12.0 \mathrm{~mm}$ (holotype). A= labium; $\mathrm{B}=$ maxilla 1 ; $\mathrm{C}=$ maxilla 2 ; $\mathrm{D}=$ maxilliped; $\mathrm{E}=$ urosome with uropods 1 2; F= uropod 1; G= uropod 2; $\mathrm{H}=$ telson.2; $F=\operatorname{uropod} 1 ; \mathrm{G}=\operatorname{uropod} 2 ; \mathrm{H}=$ telson. 
Pereopods 3 and 4 rather similar to each other, moderately slender. Pereopod 3: article 2 along anterior margin with 4 proximal long setae and 7-8 distal short setae, along posterior margin with proximal long setae and distal short setae (fig. 1E); articles 4-6 of unequal length (ratio: 55:33:44); article 3 along posterior margin with bunch of long setae; article 4 along posterior margin with 4 bunches of setae (the longest setae are much longer than diameter of article itself) (fig. 1E); article 5 along posterior margin with 3 spines mixed with single short setae; article 6 along posterior margin with 5 groups of short spines and setae. Dactylus strong, much shorter than article 6 (ratio: 19:44), along inner margin with one strong spine and seta near basis of the nail, along outer margin with one median plumose seta (fig. 1F), nail hardly longer than pedestal (ratio: 25:23).

Pereopod 4: pilosity of article 2 likes that in pereopod 3; articles 3 and 4 at posterior margin with bunch of longer setae (fig. 1G). Articles 4-6 of unequal length (ratio: 50:34:44); article 4 along posterior margin with 4 bunches o setae (the longest setae are longer than diameter of article itself); article 5 at posterior margin with short spines and setae; article 6 along posterior margin with bunches of short spines and setae. Dactylus much shorter than article 6 (ratio: 19:44), along inner margin with 1-2 strong spines (fig. $1 \mathrm{H}, \mathrm{I}$ ), at outer margin with one median plumose seta; nail nearly as long as pedestal.

Pereopods 5-7 moderately strong, Pereopod 5 remarkably shorter than pereopods 6 and 7; article 2 longer than broad (ratio: 76:46), along anterior margin with several longer spine-like setae, along posterior almost straight margin with nearly 11 short setae, ventroposterior lobe small (fig. 4A). Articles 4-6 of unequal length (ratio: 51:55:62), article 4 along anterior margin with 4 bunches of long setae (the longest setae slightly longer than diameter of article itself), along posterior margin with 3 short spine-like setae (fig. 4A); article 5 at anterior margin with 3 groups of spines and longer spine-like setae, along posterior margin with 3 groups of short spines; article 6 along both margins with bunches of short spines accompanied at anterior margin by single setae. Article 6 is slightly shorter than article 2 (ratio: 76:62), with distal bunch of long setae exceeding half of article 6-length.

Dactylus moderately slender, much shorter than article 6 (ratio: 21:62), at inner margin with one strong spine and seta near basis of the nail, along outer margin with one median plumose seta (fig. 4B); nail shorter than pedestal (ratio: 23:30) (fig. 4B).

Pereopod 6: article 2 much longer than broad (ratio: 90:53), along anterior margin with several longer spine-like setae (fig. 4C), along posterior hardly concave margin bearing nearly 12 short setae, ventroposterior lobe short. Articles 4-6 of unequal length (ratio: 69:75:95), article 4 at anterior margin with 5 bunches of setae, along posterior margin with 4 bunches of spines (fig. 4C); articles 5 and 6 along both margins with bunches of spines mixed with setae. Article 6 is longer than article 2 (ratio: 95:90), with distal bunch of setae much shorter than half of article 6-length (fig. 4D). 


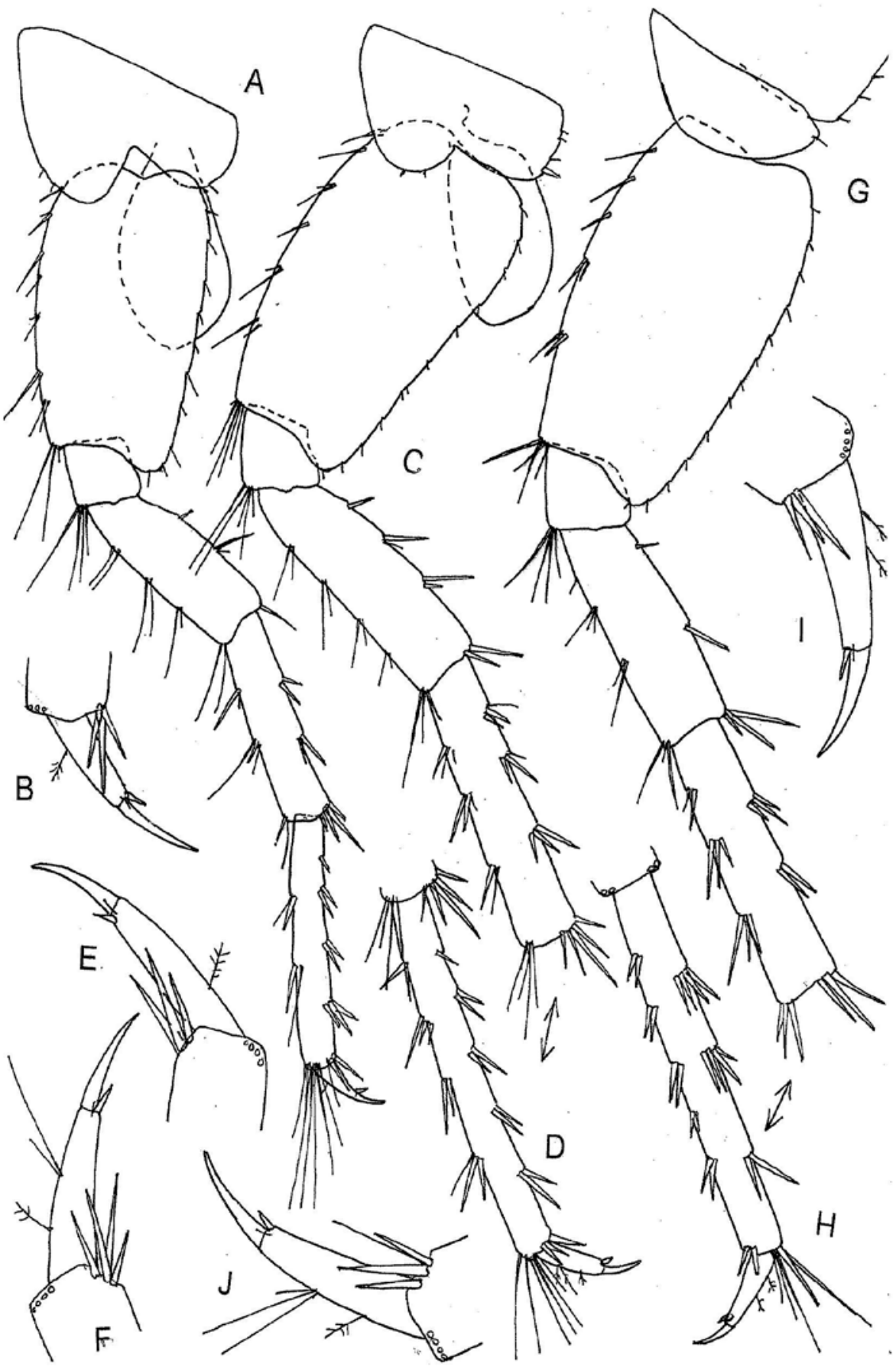

Fig. 4. Niphargus spiritus, sp. n., Fuente Aizpara, male $12.0 \mathrm{~mm}$ (holotype). A-B= pereopod 5; C-D-E-F= pereopod 4; G-H-I-J= pereopod 7. 
Dactylus is moderately slender, much shorter than article 6 (ratio: 30:95), along inner margin with one strong spine and seta near basis of the nail, along outer margin with one median plumose seta (fig. 4E) and 0-1 pair of simple setae (fig. 4F); nail is shorter than pedestal (ratio: 25:50 or 28:46).

Pereopod 7: article 2 longer than broad (ratio: 90:56), along anterior margin with 6 groups of spine-like setae, along posterior slightly convex margin with nearly 13 short setae, ventroposterior lobe short (fig. 4G). Articles 4-6 of unequal length (ratio: 62:73:100); article 4 at anterior margin with bunches of setae, along posterior margin with spines; articles 5 and 6 along anterior and posterior margin with bunches of spines (fig. 4G, H).

Article 6 is longer than article 2 (ratio: 100:90), bearing distal bunch of longer setae (fig. 4H). Dactylus is much shorter than article 6 (ratio: 32:100), at inner margin with one strong spine and seta (fig. 4J), along outer margin with 2 median plumose setae (fig. 4 I) or one plumose seta and one bunch of 3 simple setae (fig. 4J); nail is shorter than pedestal (ratio: 32:48, or 29:50).

Pleopods 1-3 with 2 retinacula each. Peduncle of pleopod 1 with one distoanterior strong seta (fig. 5E); peduncle of pleopod 2 with one distoanterior seta (fig. 5F); peduncle of pleopod 3 with 3 posterior single strong setae (fig. $5 G)$.

Uropod 1: peduncle slightly longer than rami, with dorsoexternal row of spines, on dorsointernal margin with 2 median setae and distal spine (fig. 3E, F); outer ramus bearing 4-5 distal and several lateral short strong spines, as well as 2 lateral bunches of simple setae (fig. 3F)' inner ramus much longer than outer ramus, bearing 4 distal and 3 lateral strong short spines, as well as 2 lateral bunches of simple setae (fig. 3F).

Uropod 2: peduncle with lateral and distal strong short spines (fig. 3G); inner ramus is slightly longer than outer ramus, both rami with 2-3 lateral and 4-5 distal strong short spines (fig. 3G).

Uropod 3 long and slender (fig. 5H); peduncle longer than broad (ratio: 44:17), bearing bunch of distal short spines (fig. 5G); inner ramus scale-like, much smaller than peduncle and bearing 2 distal spines and one simple seta. Outer ramus 2-articulated: first article poorly longer than second article (ratio: 136:122), bearing along both margins several bunches of short spines (fig. 5H); second article slender, along inner margin and tip provided with bunches of simple setae (fig. $5 \mathrm{H}$ ).

Telson nearly as long as broad, deeply incised (fig. 3H); each lobe with 3-4 long distal spines; 2-3 outer lateral spines are implanted on each lobe; spines at inner margin and face of each lobe absent (fig. 3H).

Coxal gills ovoid, not reaching ventral tip of corresponding article 2 (figs. 1E, G; 2A, D; 4A, C). 


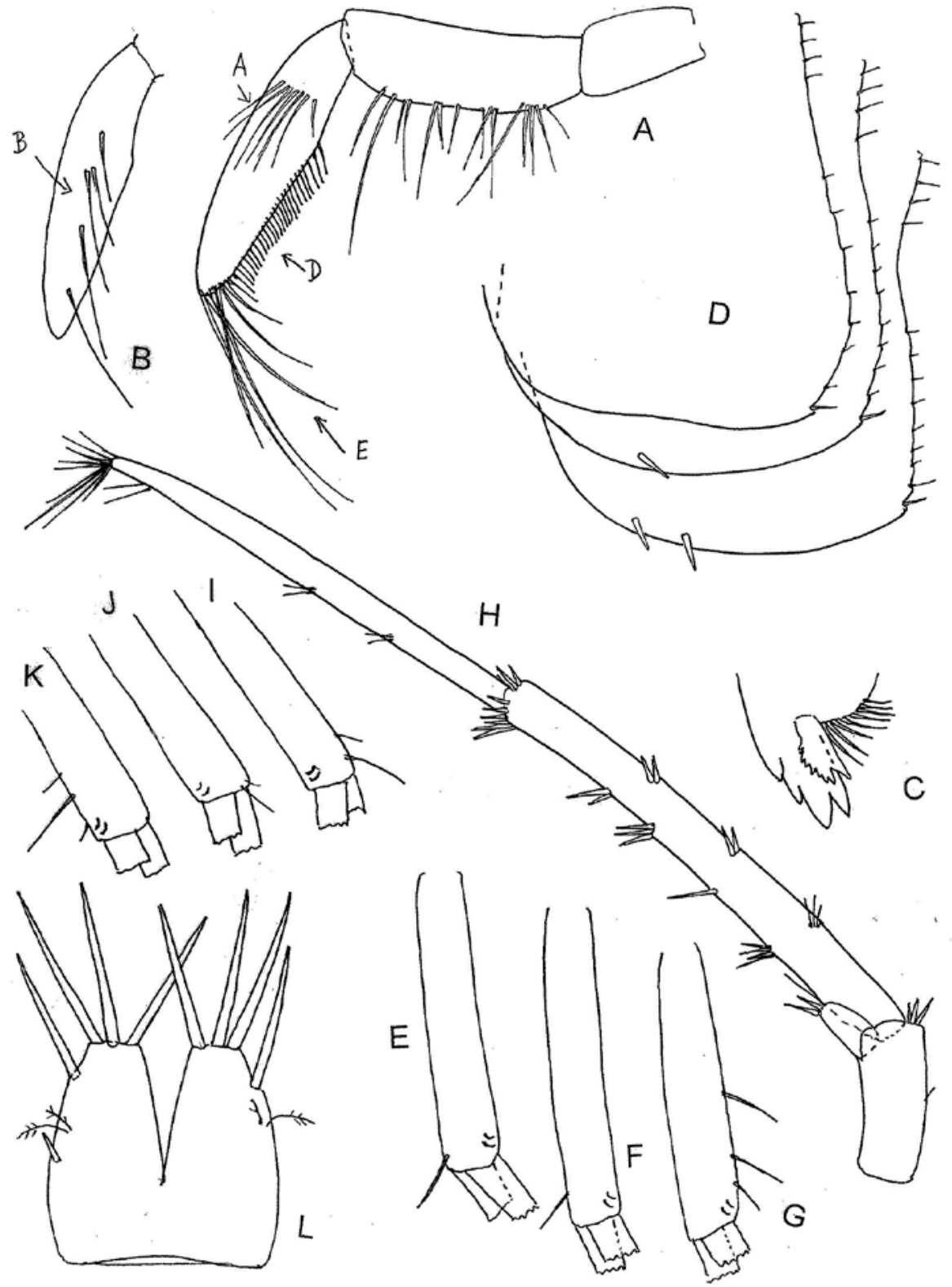

Fig. 5. Niphargus spiritus, sp. n., Fuente Aizpara, male $12.0 \mathrm{~mm}$ (holotype). $\mathrm{A}=$ mandible palpus, outer face $[\mathrm{A}=\mathrm{A}$-setae; $\mathrm{D}=\mathrm{D}$-setae; $\mathrm{E}=$ distal E-setae]; $\mathrm{B}=$ distal palpus article of mandible, inner face $[\mathrm{B}=\mathrm{B}$-setae $]$; $\mathrm{C}=$ right mandible incisor, lacinia mobilis and rakers; $\mathrm{D}=$ epimeral plates 1-3; $\mathrm{E}=$ peduncle of pleopod $1 ; \mathrm{F}=$ peduncle of pleopod 2; $\mathrm{G}=$ peduncle of pleopod $3 ; \mathrm{H}=$ uropod 3.

Female $7.8 \mathrm{~mm}$ (paratype). I= peduncle of pleopod $1 ; \mathrm{J}=$ peduncle of pleopod 2; $\mathrm{K}=$ peduncle of pleopod 3; $\mathrm{L}=$ telson. 
FEMALE $7.8 \mathrm{~mm}$ (paratype) with setose oostegites: Body moderately slender, metasomal segments 1-3 with 8-10 setae on each dorsoposterior margin (fig. 7E). Urosomal segment 1 on each dorsolateral side with one seta; urosomal segment 2 on each dorsolateral side with one spine and 0-1 seta; urosomal segment 3 naked.

Epimeral plates are hardly more angular than these in male. Epimeral plate 1 with ventroposterior corner marked by one spine-like seta, posterior slightly convex margin is provided with 5-6 short setae (fig. 7E); epimeral plate 2 with marked ventroposterior corner by one spine-like seta and less convex posterior margin bearing 6-7 short setae. Epimeral plate 3 distinctly angular with marked ventroposterior corner by one spine-like seta, posterior margin slightly inclined and almost straight, bearing several short setae. Epimeral plate 2 with one subventral spine, epimeral plate 3 with 2 subventral spines (fig. 7E).

Head like that in male. Antenna 1 slightly longer than half of body-length (ratio: 49:78), main flagellum with 25 articles. Antenna 2 like that in male, flagellum consisting of 12 articles.

MOUTHPARTS. Mandible: palpus article 2 with 12 setae; palpus article 3 falciform, bearing nearly 23 D-setae, 6 E-setae, one group of 6 A-setae, on inner face appear 5 B-setae (2-2-1).

Maxilla 1: inner plate with 2 setae, outer plate with 7 spines ( 5 spines with one lateral tooth, one spine with 2 teeth, one spine with 3-4 small teeth).

Maxilliped: inner plate with 3 distal spines; palpus article 3 at outer margin with one median and one distal bunch of setae; article 4 at inner margin with 2 setae near basis of the nail, at outer margin with one median seta.

Coxa 1 broader than long (ratio: 45:37), with subrounded ventroanterior corner and bearing nearly 11 marginal setae (fig. 6A). Coxa 2 is slightly longer than broad (ratio: 50:47), bearing nearly 9 unequal marginal setae (fig. 6C). Coxa 3 longer than broad (ratio: 65:53), bearing nearly 8 marginal unequal setae (fig. 7A). Coxa 4 hardly longer than broad (ratio: 55:53), with nearly 10 marginal unequal setae (fig. 7C).

Coxa 5 broader than long (ratio: 65:43), anterior lobe is only poorly shorter than coxa 4 (fig. 8A). Coxa 6 remarkably smaller than coxa 5, broader than long (ratio: 53:35) (fig. 8D). Coxa 7 entire, broader than long (ratio: 46:22) (fig. 8G).

Gnathopods 1 and 2 relatively small, propodus is nearly as large as corresponding coxa. Gnathopod 1 is only slightly smaller than gnathopod 2, with article 2 bearing a row of long setae along anterior margin and bunches of long setae along posterior margin (fig. 6A). Article 3 at posterodistal corner with one bunch of long setae; Article 5 is shorter than propodus (ratio: 32:48), along anterior margin with one bunch of distal long setae (fig. 6A). 

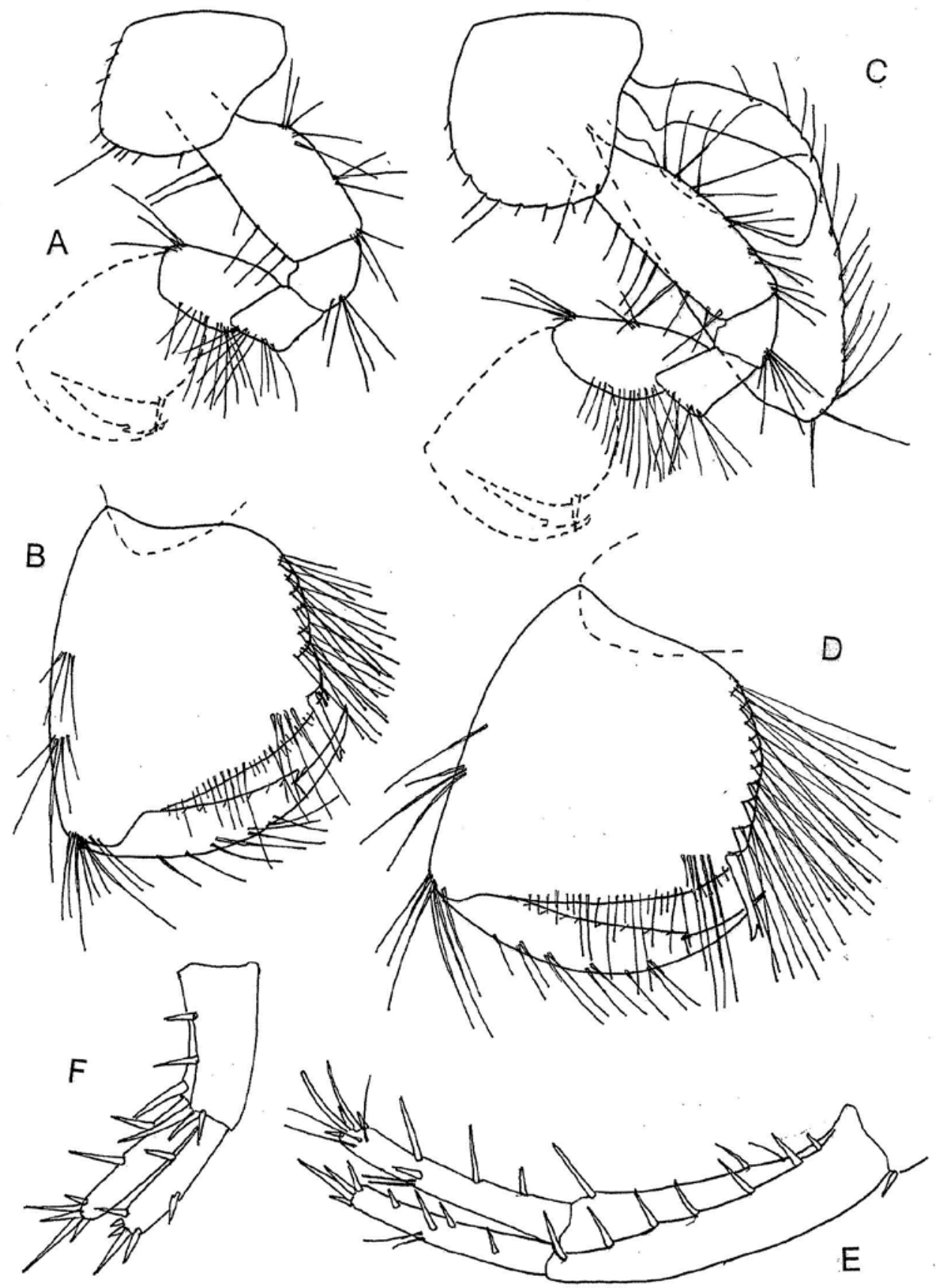

Fig. 6. Niphargus spiritus, sp. n., Fuente Aizpara, female $7.8 \mathrm{~mm}$ (paratype). A$\mathrm{B}=$ gnathopod 1 , outer face; $\mathrm{C}-\mathrm{D}=$ gnathopod 2 , outer face; $\mathrm{E}=\operatorname{uropod} 1 ; \mathrm{F}=$ uropod 2 
Propodus trapezoid, slightly longer than broad (ratio: 85:70), along posterior margin with 6 transverse rows of setae (fig. 6B). Palm inclined nearly half of propodus-length, slightly convex, defined on outer face by one corner $\mathrm{S}$ spine accompanied laterally by 3 slender L-spines and 4 facial M-setae, on inner face by one subcorner R-spine. Dactylus reaching posterior margin of propodus, along outer margin are attached 8 setae, along inner margin is attached row of short setae (fig. 6A).

Gnathopod 2: article 2 along anterior margin with row of long setae, along posterior margin with several bunches of long setae; article 4 with posterodistal bunch of long setae; article 5 is shorter than propodus (ratio: 40:45), along anterior margin with 2 bunches of setae (fig. 6C). Propodus trapezoid, slightly longer than broad (ratio: 87:78), along posterior margin with 9 transverse rows of setae (fig. 6D). Palm inclined slightly less than half of propodus-length, convex, defined on outer face by one corner S-spine accompanied laterally by 3 slender L-spines and 5 facial setae, on inner face by one subcorner R-spine. Dactylus reaching posterior margin of propodus, along outer margin provided with 10 single or paired setae, on inner margin with row of short setae (fig. 6D).

Pereopods 3 and 4 are moderately slender. Pereopod 3: article 2 along anterior margins with long proximal setae and short distal setae; along posterior margin appear long setae in proximal part and shorter setae in distal part (fig. 7A); articles 3 and 4 at posterior margin with long setae (the longest setae much longer than diameter of articles themselves). Articles 4-6 of different length (ratio: 55:33:40). Article 4 along posterior margin with 4 groups of setae (the longest setae are much longer than diameter of article itself). Article 5 at posterior margin with 3 bunches of spines and short setae; article 6 along posterior margin with 5 bunches of short spines and setae. Dactylus much shorter than article 6 (ratio: 20:40), along inner margin with 2 strong spines, along outer margin with one median plumose seta (fig. 7B); nail shorter than pedestal (ratio: 32:37).

Pereopod 4: article 2 bearing along anterior and posterior margin several proximal long setae and distal short setae. Articles 4-6 of unequal length (ratio: 50:27:40); article 4 at posterior margin with 3 bunches of setae (fig. 7C); articles 5 and 6 along posterior margin with bunches of short spines. Dactylus much shorter than propodus (ratio: 20:40), along inner margin with 2 strong spines, along outer margin with one median plumose seta (fig. 7D); nail nearly as long as pedestal.

Pereopods 5-7 moderately slender. Pereopod 5 is shorter than pereopods 6 and 7 (fig. 8A, D, G), with article 2 longer than broad (ratio: 67:43), along anterior margin with several spine-like setae (fig. 8A), along posterior margin with nearly 10 short setae; ventroposterior lobe poorly visible. Articles 4-6 of 
unequal length (ratio: 48:48:58); articles 2, 3 and 4 along anterior margin with bunches of long setae; articles 5 and 6 along both margins with bunches of strong spines (fig. 8A). Article 6 is slightly shorter than article 2 (ratio: 58:67), with distal bunch of long setae (fig. 8A). Dactylus is much shorter than article 6 (ratio: 21:58), along inner margin with 1-2 spines and one seta (fig. $8 \mathrm{~B}, \mathrm{C}$ ), at outer margin with one median plumose seta; nail is shorter than pedestal (ratio: 33:50).

Pereopod 6: article 2 longer than broad (ratio: 86:53), along anterior margin with row of spine-like setae, along posterior margin with nearly 10 short setae (fig. 8D), ventroposterior lobe is short but developed. Articles 4-6 of unequal length (ratio: 63:70:91); articles 3 and 4 along anterior margin with bunches of long setae; article 4 at posterior margin with 3 single spines accompanied by single short setae; articles 5 and 6 along both margins with bunches of strong spines. Article 6 is longer than article 2 (ratio: 91:86), bearing distal bunch of long setae (fig. 8E). Dactylus much shorter than article 6 (ratio: 29:91), along inner margin with one strong spine and seta near basis of the nail (fig. 8F), along outer margin with one median plumose seta; nail shorter than pedestal (ratio: 37:67).

Pereopod 7: article 2 slightly ovoid, longer than broad (ratio: 88:56), along anterior margin with 5 groups of spine-like setae, along posterior margin with nearly 13 short setae and one small spine (fig. 8G), ventroposterior lobe short but developed. Articles 4-6 of unequal length (ratio: 59:66:95); article 4 at anterior margin with spines and setae, along posterior margin with spines; articles 5 and 6 along both margins with strong spines. Article 6 is slightly longer than article 2 (ratio: 95:88), with distal bunch of long setae.

Dactylus is much shorter than article 6 (ratio: 31:96), along inner margin with one strong spine and seta near basis of the nail, along outer margin with one median plumose seta (fig. 8 I); nail shorter than pedestal (ratio: 37:69).

Pleopods 1-3 with 2 retinacula each. Peduncle of pleopod 1 with 2 distal setae along anterior margin (fig. $5 \mathrm{I}$ ); peduncle of pleopod 2 with 2 distal setae at anterior margin (fig. 5J); peduncle of pleopod 3 with 3 setae along posterior margin (fig. 5K).

Uropod 1: peduncle longer than rami, with dorsoexternal row of spines; at dorsointernal margin with one spine and one seta (except distal spine) (fig. 6E). Outer ramus is slightly shorter than inner ramus, bearing several lateral and distal strong spines and one lateral pair of short simple setae (fig. 6E); inner ramus with several lateral and distal strong spines and bearing 2 median and 3 distal short simple setae.

Uropod 2: peduncle with lateral and distal strong spines (fig. 6F); inner ramus is slightly longer than outer ramus, both rami with lateral and distal strong spines (fig. 6F). 
Uropod 3: peduncle longer than broad (ratio: 44:23), bearing distal spines (fig. 7F). Inner ramus much shorter than peduncle, bearing 3 distal spines (fig. 7F). Outer ramus 2-articulated: first article along outer margin with 3 bunches of strong spines and one bunch of short simple setae, along inner margin with 5 bunches of strong spines; 3 longer plumose setae are attached near bunches of spines (fig. 7F); second article much shorter than first one (ratio: 50:130) bearing along both margins the bunches of simple setae; the tip is pointed and naked

Telson as long as broad, incised nearly $2 / 3$ of telson-length (fig. 5L); each lobe with 3 distal and one outer marginal very long spine; one short spine is attached in the middle of outer margin of one lobe; a pair of short plumose setae is attaches near the middle of outer margin in each lobe (fig. 5L).

Coxal gills not exceeding corresponding article 2 (figs. 6C; 7A, C; 8D. Oostegites are very broad, with marginal setae (figs. 6C; 7A).

\section{VARIABILITY}

Maxilla 1 inner plate with 1-2 setae in males and females; 1-2 spines of outer plate provided with 2 lateral teeth. Maxilliped inner plate is with 3-4 distal spines.

The one normal and often one additional spine are present on some of pereopod-dactyls [on pereopod 3, pereopod 4, pereopod 5], but pereopods 6 and 7 were always with only one spine at inner margin. Some specimens are without this additional spine. Evidently, the presence of additional spine on some dactyls of pereopods 3-5 is characteristic for this species, despite the fact that some specimens are without it.

Article 2 of pereopods 5-7 is with well to poorly marked ventroposterior lobe. Urosomal segment 1 in males and females is always with 1 seta only on each dorsolateral side. Urosomal segment 2 on each dorsolateral side in males is with 2 setae or one spine and seta, in females with one spine and one seta, or 2 spines. Telson is with long spines. Females have usually poorly more angular epimeral plate 3 than the males. Peduncle of uropod 1 along dorsointernal margin is with 1-2 median setae or one spine and one seta (except distal spine).

The further discovery of this species in other localities will show the limits of variability of this species.

HOLOTYPE: male $12.0 \mathrm{~mm}$; paratype female $7.8 \mathrm{~mm}$. Holotype and paratypes are deposited in Karaman`s Collection in Podgorica, Montenegro.

DISTRIBUTION: Known from type-locality only.

DERIVATIO NOMINIS. The name "spiritus" arrives from the Latin word "spiritus", adequate word "spiritus” in English. 


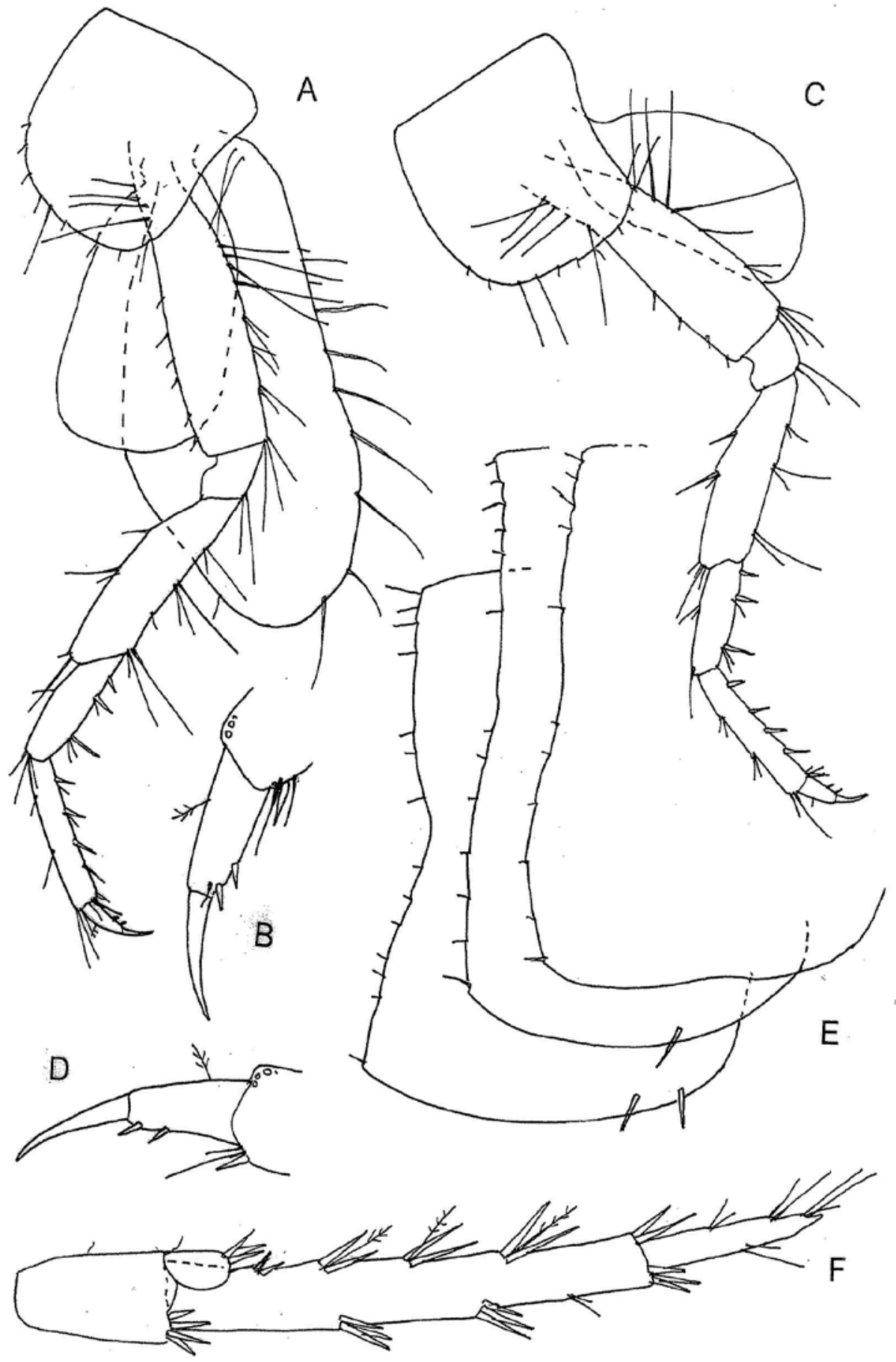

Fig 7. Niphargus spiritus, sp. n., Fuente Aizpara, female $7.8 \mathrm{~mm}$ (paratype). A$\mathrm{B}=$ pereopod $3 ; \mathrm{C}-\mathrm{D}=$ pereopod $4 ; \mathrm{E}=$ epimeral plates $1-3 ; \mathrm{F}=$ uropod 3. 


\section{REMARKS AND AFFINITIES}

Niphargus spiritus, sp. n. is very close to Niphargus ciliatus Chevreux, 1906 [Loc. typ.: Grotte de Meailles, Valee de la Vaire, affluent du Var, France]. As the description of this species was scarce, Ginet (1988 and 1991) redescribed this species more in detail, and based on this description is evident that $\mathrm{N}$. spiritus, sp. $n$. is rather similar to $N$. ciliatus by various characters: elongated uropod 3, elongated inner ramus of uropod 1 in males, shape of pereopods 3-7 except dactyls, by pleopods with 2 retinacula, etc. But $N$. ciliatus differs from N. spiritus by strong dactylus of pereopods 3-7 bearing higher number of spines each, by inner plate of maxilla 1 bearing 2-4 setae, telson with distal and inner marginal and facial short spines, elevated number of dorsolateral spines on urosomal segments 1 and 2, slightly pointed epimeral plate 3 in male, etc.

Margalef (1952) described new taxon Niphargus ciliatus cismontanus from Spain [Loc. typ.: Guipuzcoa (Aranzazu: cueva de Guesaltza] [= Niphargus cismontanus Margalef, 1952], provided with strongly angular or almost pointed epimeral plate 3, dactylus of pereopod 7 with 4 spines, maxilla 1 inner plate with 2 setae, outer plate with 8 spines bearing one lateral tooth; telson with short spines along outer and inner margin, face and tip of each lobe.

Margalef (1970) figured partially again this species: epimeral plate 3 poorly angular, nearly like that in our specimens, telson with short spines along inner margin and tip only, and dactylus of pereopod 7 with 6 spines along inner margin.

The large species Niphargus plateau (= elongatus) Chevreux, 1901 [Loc. typ.: Nantes] differs by dactylus of pereopods 5-7 bearing one seta along inner margin only [no spines], size of male $25 \mathrm{~mm}$; uropod 1 peduncle with dorsointernal row of spines, etc.

Chevreux described (1901: 173) Niphargus plateau robustus, nov. var. [Loc typ.: Sare Cave, Basses Pyrenees, France], and cited it also for Beaume-lesMessieurs, Jura; and "gouffre" de Padirac, Lot; grotte de Saint Mesme, Isere; Besse, Puy-de-Dome [= Niphargus robustus Chevreux, 1901].

Chevreux figured entire male of this species only, with rectangular epimeral plate 3, mentioning longer coxae, and elongated uropod 3 in males only, with remarks that "this variety don `t differ significantly from $N$. plateau". On page 232 (1901) he figured uropod 3 of female from Robine with short distal article of outer ramus. France. Ginet (1991) presented several figures of this species: dactylus of pereopod 3 and pereopod 7 with 3 spines along inner margin, inner plate of maxilliped with 5 spines, urosomal segment 2 with 6 spines on each dorsolateral side, etc.

Chevreux \& Fage (1925) cited $N$. robustus and figured male $21 \mathrm{~mm}$ from Padirac with large gnathopods 1-2 propodus exceeding the width of corresponding coxae, propodus palm inclined over half of propodus-length, and telson bearing short distal and outer marginal spines. Later nobody redescribed this taxon in detail, but based on known taxonomical characters of $N$. robustus, our specimens from Fuente Aizpara are not identic with N. robustus. 


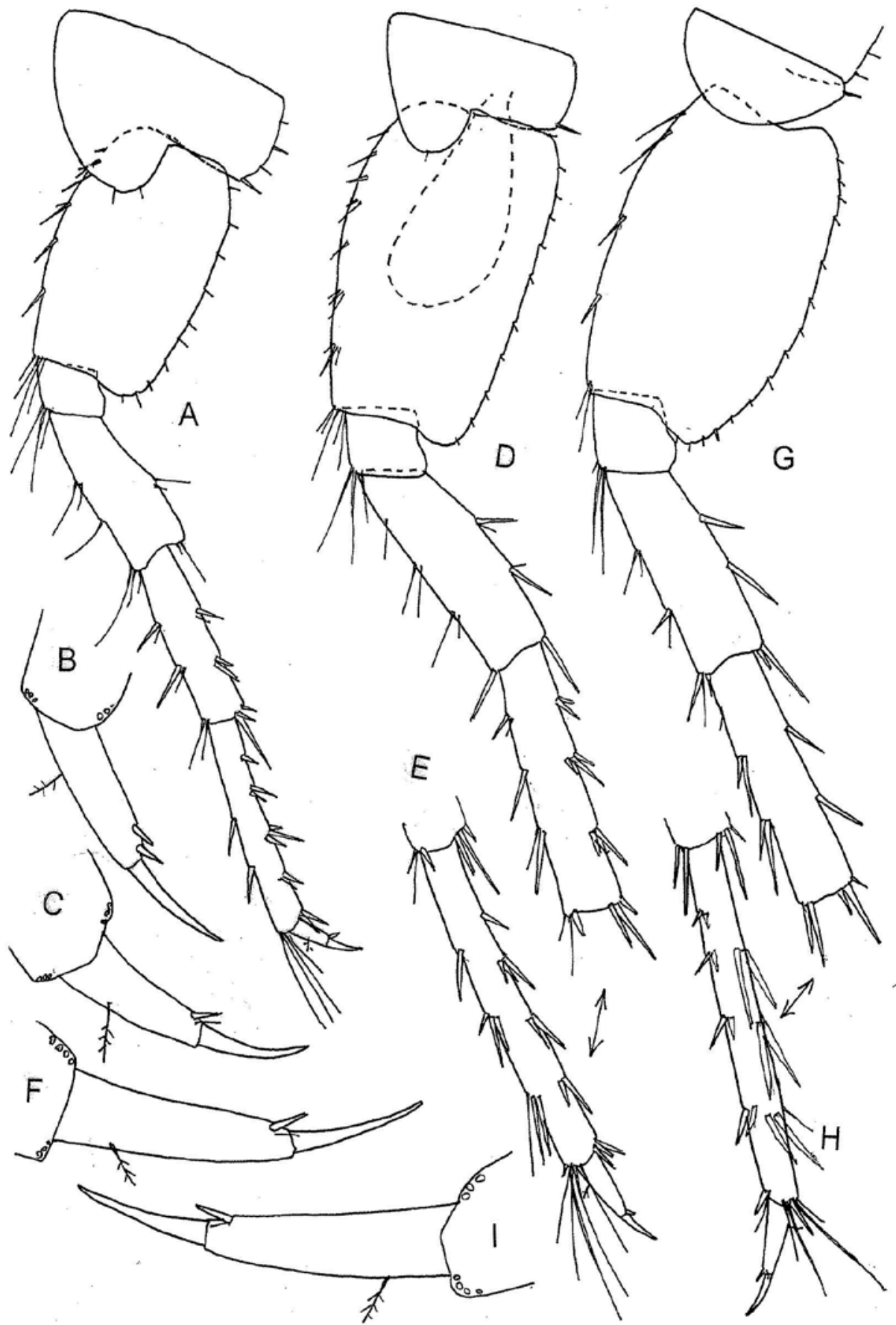

Fig. 8. Niphargus spiritus, sp. n., Fuente Aizpara, female $7.8 \mathrm{~mm}$ (paratype). A-B-C= pereopod 5; D-E-F= pereopod 6; G-H-I= pereopod 7. 
Niphargus virei Chevreux, 1896 [Loc. typ.: Grotte de Arbois, de Beaumeles-Messieurs, de Baume- les-Dames, Jura, France] has long lobed coxa 4, epimeral plates strongly angular to poorly acute, telson with 2 facial and 5-6 distal short spines; maxilla 1 inner plate with 3 setae, dactylus of pereopods 3-7 with one spine, etc.

Niphargus balazuci Schellenberg 1951 [Loc. typ.: Grotte de Colombier in Valon (bank of Ardeche river, Ardeche, France] is characterized by equal rami of uropod 1 in male, inner plate of maxilla 1 with 1-3 setae, dactylus of pereopods 3 and 4 with one spine at inner margin, dactylus of pereopod 5 with 2 spines, and dactylus of pereopods 6 and 7 with 3-4 spines at inner margin, epimeral plates distinctly angular, telson bearing distal and outer marginal spines.

Karaman, G. (2016) described from northern Italy Niphargus rotundus, sp. n. [Loc. typ.: Well in Montelupo Albeze, $450 \mathrm{~m}$ about sea level (a.s.l.) (Cuneo, Piemonte], species with additional spines on dactylus of pereopods and almost subrounded epimeral plates, but this species differs from $N$. spiritus by numerous distal, marginal and facial short spines on telson, elevated number of spines on dactylus of pereopods 3-7, by stout pereopods 3-7, by large body, etc.

Niphargus sestoputeanus G. Karaman, 2016 [Loc. typ.: Sesta Godano, Passo del Rastrello, $1000 \mathrm{~m}$ a.s.l. (N. of La Spezia) is also provided with additional spines on dactylus of pereopods, but differs from our species by elongated inner ramus of uropod 3 in male, by pointed epimeral plates in males and females, by strong dactylus of pereopods 3-7 bearing higher number of spines, by higher number of setae on maxilla 1 inner plate, etc.

Niphargus puteanus Koch, in Panzer, 1836 [Loc. typ.: Weichelmuhle near Ratisbonne (= Regensburg), Germany] was mentioned by various authors from many localities of Europe (often erroneously), because the good description of this species was not published. Stock (1974) redescribed this species from Weichselmühle, Ratisbonne, Germany]. We compared the specimens from this locality with $N$. spiritus from Spain, and $N$. puteanus differs from our species by remarkably higher coxae, by more pointed epimeral plates, by presence of dorsointernal row of spines on uropod 1 peduncle in male, almost quadrate propodus of gnathopod 2, by higher number of setae on maxilla 1 inner plate, shorter spines on telson, etc.

The species Niphargus rhenorhodanensis Schellenberg, 1937 [Loc. typ.: Rumingen, N of Lorrach, Germany], redescribed by Ginet (1985), and N. orbis G. Karaman, 2013 [Loc. typ.: Calizzano, Alpi Ligure, Rio di Valle, Italy] are rather similar to our species, but both of them differ from $N$. spiritus by absence of additional spines on dactylus of pereopods 3-7. The most of known Niphargus species from France are poorly or partially described, and some of its taxonomical characters are still unknown. By this way to establish the real taxonomical relations between newly described taxa and taxa described one century ago, remains very difficult and rather hazardous. The further studies and redescription of known taxa will help in establishing of the real relationships 
among various Niphargus taxa and understand the limits of variability of each taxon.

\section{CONCLUSION}

The fauna of the genus Niphargus Schiödte, 1849 (Amphipoda Gammaridea, fam. Niphargidae) is very poorly known from the subterranean waters in Spain, and only several species and subspecies of this genus have been described or mentioned from various localities of Spain. Genus Niphargus settled the subterranean waters in northern part of Spain only (Karaman, G. 1986b), replaced in other part of country by members of genus Haploginglymus Mateus \& Mateus, 1958. The known members of genus Niphargus from Spain are related to these of France, but scarce description of many taxa from France made very difficult recognition of real relations among all known taxa in France, and consequently, in Spain also.

\section{ACKNOWLEDGEMENTS}

I am thankful to Prof. Dr. Jos Notenboom from Holland for the loan of the material used in this study. I thank also Montenegrin Academy of Sciences and Arts for the support in the realization of this work.

\section{REFERENCES}

Chevreux, E. 1896. Sur un amphipode d`eau douce, Niphargus Virei, n. sp., provenant des grottes du Jura. - Bulletin Histoire Naturelle, Paris, 1: 136-137 [=Bull. Mus. Paris 4: 136-137?].

Chevreux, E. 1901. Amphipodes des eaux souterraines de France et d’Algerie. I-VI. Bulletin de la Société zoologique de France: 168-222.

Chevreux, E. 1906. Niphargus ciliatus n. sp., in: Peyerimhoff, P.: Recherches snear Pentling, ur la faune cavernicole des Basses-Alpes.- Annales de la Societe Entomologique de France, 75: 203-222.

Ginet, R. 1985. Redescription du type de l`Amphipode hypoge Niphargus rhenorhodanensis Schellenberg, 1937. - Crustaceana, 48 (3): 225-243.

Ginet, R. 1988. Description d'une neotype ex choix d'une nouvelle localite-type pour le crustace stygobie. Niphargus ciliatus Chevreux 1906 (Amphipode). Bulletin Mensuel de la Societe Linneenne de Lyon, 57 (7): 215-231.

Ginet, R. 1991. Bilan systematique du genre Niphargus en France. - Biologie Animale et Ecologie, Lab. Hydrob. Ecol. Souterr. Universite Claude-Bernard Lyon, pp. 1-26.

Karaman, G. 1969. XXVII. Beitrag zur Kenntnis der Amphipoden. Arten der Genera Echinogammarus Stebb. und Chaetogammarus Mart. an der jugoslawischer Adriaküste. - Glasnik Republičkog zavoda za zaštitu prirode i Prirodnjačke zbirke u Titogradu, 2: 59-84.

Karaman, G. 1986a. Discovery of Niphargus delamarei Ruffo 1954 in Spain, with first description of females (Gammaridea: Niphargidae) (Contribution to the Knowledge of the Amphipoda 154). - Poljoprivreda i šumarstvo, Titograd, 33 (2-3): 29-42. 
Karaman, G. 1986b. Description of Haploginglymus mateusi, new species of subterranean Gammaridea from Iberian Peninsula with remarks to other taxa of this genus (Fam. Niphargidae). (Contribution to the Knowledge of the Amphipoda 157). - Poljoprivreda i šumarstvo, Titograd, 32 (1): 75-90.

Karaman, G. 2012. Further investigations of the subterranean genus Niphargus Schiödte, 1849 (fam. Niphargidae) in Serbia. (Contribution to the Knowledge of the Amphipoda 264). - Agriculture and Forestry, Podgorica, 58 (2): 45-64.

Karaman, G. 2013. New data on genus Niphargus Schiodte, 1849 (Fam. Niphargidae) from Italy and Macedonia (Contribution to the Knowledge of the Amphipoda 272).- Agricultura \& Forestry 59 (4): 17-43.

Karaman, G. 2015a. Two new members of the family Niphargidae (Gammaridea) from Spain (Contribution to the Knowledge of the Amphipoda 281).Biologia Serbica, 15 (1-2): 3-21, Novi Sad.

Karaman, G. 2015b. New data on two subterranean species of the family Niphargidae from Spain, Niphargus gallicus Schell., 1935 and N. delamarei Ruffo, 1954 (Contribution to the Knowledge of the Amphipoda 282).Contributions, Section of Natural, Mathematical and Biotechnical Sciences, MASA, 36 (2): 105-120.

Karaman, G. 2016. On two new Niphargus species (Fam. Niphargidae) from Italy (Contribution to the Knowledge of the Amphipoda 288).- Ecologica Montenegrina 5: 70-89.

Koch, C.L. In Panzer, 1836. Deutschlands Crustaceen, Myriapoden und Arachniden, Ein Beitrag zur deutschen Fauna. G.A.W. Herrich-Schäfer, Regensburg 183540, 5 (1): 1-24.

Margalef, R. 1952. La vida en las aguas dulces de los alrededores del Santuario de Nuestra Senora de Aranzazu (Guipuzcoa). - Munibe, San Sebastian, pp. 1-36.

Margalef, R. 1970. Anfipodos recolectados en aguas subterraneas del Pais Vasco. Munibe (San Sebastian), Sociedad de Ciencias Naturales Aranzadi, 22 (3-4): 169-174.

Mateus, A. \& Mateus, E. 1958. Un nouveau genre et une nouvelle espece d`Amphipode troglobie du Portugal. - Publicaçoes do Instituto de Zoologia "Dr. Augusto Nobre”, Faculdade de Ciencias do Porto, Coimbra, 59: 1-15, figs. 1-11.

Schellenberg, A. 1937. Niphargen (Amphipoda) des Französichen Jura und Jugoslawiens.- Zoologischer Anzeiger, 120 (7-8): 161-169.

Schellenberg, A. 1951. Un Niphargus nouveau du Sud-est de la France. - Bulletin du Muséum National d`Histoire Naturelle, Paris, 2-e ser., 23 (2): 187-189.

Stock, J.H. 1974. Redescription de l’Amphipode hypoge Niphargus puteanus (Koch in Panzer, 1836), basee sur du materiel topotypique.- Bijdragen tot de Dierkunde, 44 (1): 73-82. 